\title{
PREMIUM RATES IN THE GERMAN MOTOR INSURANCE BUSINESS
}

\author{
Johannes Mehring \\ Dusseldorf, West Germany
}

\section{TERM OF PRICE-FIXING AGREEMENTS}

In his report to the XVIth International Congress of Actuaries in Brussels [5] ${ }^{1}$ ) in 1960 the author has given a survey of the German Motor Insurance Business and in this it was mentioned that a change might be expected from the flat-tariff prescribed by law into individual tariffs for every insurance company. The Federal Ministry of Economics decided this question at the end of 1959 by signing the price regulation PR I5/59 [I]. The federal price-fixing treaty had thus come to an end after several decades.

Three steps are planned for the transitional period: For the years I960 and I96I the flat-tariff remained in existence; free competition was introduced by providing for a return of premiums from technical surplus. At the beginning of 1962 the second phase of liberalisation began: Between I962-I965 each insurance company has to compute its own tariff which has to be approved by the Federal Ministry of Economics. No deviations are permitted from the approved tariffs. Nobody can tell yet what the third phase in rg66 will bring.

\section{MARKET REGULATIONS}

At the time the price-fixing agreements were cancelled it was unanimously agreed that proper competition should be maintained and that ruinous price competition which would harm the interests of victims of traffic accidents must be avoided [4]. Trusts or tariff rings were not taken into consideration. However, some market regulations were set up by co-operation between the different parties.

The benefits (insurance conditions) are the same for all insurance

1) See list of references. 
enterprises. Also there are only few alternatives in the tariff conditions.

Every insurance enterprise has freedom in the selection of rate making procedures. However, the Federal Ministry of Economics required every insurance company to compile its own statistics for the claims experience in separate risk groups [2]. This secured the maintenance of the credibility and continuity of the statistics necessary for the tariff but led automatically to a uniform tariff structure for all enterprises. The structure was closely related to the previous flat-tariff which is a class plan rated according to the type and horse-power of the vehicle. Future competition will therefore take place on the cost element of the business. Obviously, problems connected with statistics and rating procedures were of major importance. This led to the conclusion that the most competitive tariff was one with rates reflecting as nearly as possible the underlying risk situation.

\section{IMPROVEMENTS IN INSURANCE CONDITIONS}

The new tariffs provide for several improvements in benefits [3].

In liability insurance many insurers have introduced the I 000000 lump-sum coverage. For each claim, personal, material and property damages up to a maximum amount of I 000 ooo DM are covered. In future the victim of a traffic accident is also covered, even if the car was driven by an unauthorised operator.

As regards insurance of the vehicle the time value was the upper limit for determining the compensation due. In future, compensation will be increased for private passenger and station cars according to a schedule as follows:

- For damages in the first year of admission up to the list price of the car.

- For damages caused after the first year $25 \%$ of the time value, with a maximum, however, up to the list price.

For passenger accident insurance compensation is payable according to a lump sum system and will be increased by $50 \%$ if at the time of the occurrence of an accident two or more eligible persons were in the car. Other improvements have been introduced, among them being a new percentage disability table. 


\section{TARIFF STRUCTURE}

The damage structure in motor insurance is very complex and intricate [7] and for this reason no proper optimal solution for rate making procedures exists.

The following characteristics were available for a classification plan:

a) Type and power of vehicle;

b) Type and power of vehicle including an additional distinction according to the territory;

c) Type and power of vehicle including an additional distinction according to the profession of the driver;

d) Type and power of vehicle with a bonus granted for accident-free drivers.

No insurance company in Germany has adopted a rating system based on territory or profession mentioned in b) and c). A few companies have chosen a solution as in a), but the overwhelming majority has opted for a tariff according to d) [2].

The advantages and disadvantages of the characteristics "number of accident-free years" have been examined and discussed in Germany as elsewhere. The final opinion was that this characteristic was most suitable for obtaining as nearly as possible homogeneous risk groups [6].

\section{BONUS FOR ACCIDENT-FREE DRIVING}

The previous bonus system provided for a subsequent return of premiums and was no longer sufficiently attractive. Several possibilities which would permit good drivers to receive an immediate credit for a lower premium were examined from different angles. A bonus deductible from the due amount of premium and based on the calendar year as the accident-free period as well as the period for eligibility for bonus turned out to be the optimal solution [2]. Since the due date is the same for all contracts the administration of the allotment of bonuses is facilitated.

Commissions are based on the discounted premium [2].

Most companies grant a bonus on liability and/or vehicle insurance premiums [2]. The bonus scales applied are different. However, 
most companies allow a premium refund according to the following schedule:

$\begin{array}{lcc}\begin{array}{c}\text { Duration } \\ \text { of uninterrupted } \\ \text { claim free period }\end{array} & \begin{array}{c}\text { Rabate } \\ \text { class }\end{array} & \begin{array}{c}\text { Bonus in \% } \\ \text { of premium } \\ \text { due }\end{array} \\ \text { one calendar year } & I & 0 \\ \text { two calendar years } & 2 & \text { Io } \\ \text { three calendar years } & 3 & 20 \\ \text { four calendar years } & 4 & 30 \\ \text { five calendar years } & 5 & 40 \\ \text { six and more calendar years } & 6 & 50\end{array}$

If the insured transfers to another company, the claim-free period with the former insurer is taken into account. The companies exchange between themselves certificates about the claim-free period. In case of damage a driver in the higher rebate classes does not lose his bonus completely. In case of damage the insured loses two classes, i.e. a bonus of $50 \%$ is reduced to $30 \%$ in the next following calendar year. However, if the insurance cover is interrupted because the car is not used for a certain time, the whole credit is lost.

\section{SPECIAL CLASSES}

Besides the claim-free period the characteristics "territory" and "profession" are of importance for the evaluation of the underlying risk. As mentioned before the German motor insurance companies have not yet introduced specific class plans for territory or profession and the danger of tariff violation seems to be heavy. However, some items exist for such tariffs, e.g. for private passenger and combination cars.

a) in towns of less than 5,000 inhabitants,

b) for corporations, institutions, and foundations under public law as well as their employees a special bonus scale was introduced under which the maximum rebate of $50 \%$ can be obtained after three or even two continuously claim-free calendar years [2].

With these special class plans the danger involved in genuine territorial or professional class plans was avoided by connecting 
these characteristics with the claim record. Because of this condition accident-prone drivers who would be privileged owing to their profession or territory have no advantage compared with the unprivileged driver. The effects of unfair classification therefore vanish after some time.

\section{EXCEPTIONS FROM THE BONUS SYSTEM}

Where the claim frequency is small, a bonus system is hardly a practical proposition and accordingly no bonus is granted for accident-free driving in certain categories [2]. Mostly vehicles of the following kind are exempt from bonuses:
a) mopeds
b) motor bicycles
c) farm tractors
d) trailers

\section{SETTLEMENT OF MINOR CLAIMS}

Each damage reported by a policyholder which gives rise to expenditure or for which a fund has to be reserved reduces the bonus, i.e. the contribution is increased. For this reason policyholders sometimes prefer to settle a minor claim themselves. To facilitate this decision a special rule for minor claims up to $200 \mathrm{DM}$ was introduced under which whenever a policyholder pays a minor claim by himself, he will not suffer loss of bonus. However, should he cause another damage in the same year, his expenditure in respect of the minor claim will be refunded.

\section{PROFIT-SHARING}

According to regulation PR $15 / 59$ a reduction of contribution is possible by means of a participation in profits [I]. These technical profits are apportioned in equal shares to all policyholders with a claim-free driving record in the last calendar year or according to a scale depending on the period with a claim-free driving record.

IO. EXTRA CHARGE FOR ACCIDENT-PRONE DRIVERS

An extra charge system depending on the number of damages is in contradistinction to the bonus system described above [7]. Such 
a system however, leads to difficulties in practical applications. For this reason German insurers are very cautious in applying a system of extra charges for accident-prone drivers. A maximum extra charge of roo \% may be asked for six claims during one or two years, depending on the type of vehicle [2].

This system of extra charges has had a friendly reception from the public. However, under the present system its practical application in practice will be restricted to some rare cases.

\section{RATING}

Each enterprise has to compile the tariff rates itself. To facilitate the calculations and examinations the Federal Ministry of Economics has issued extensive directions and uniform blanks [2].

The elements for tariff rating are:

a) past claims experience

b) surtax for future claims evolution

c) loading for administration costs

d) profit

e) amount required for no-claim credits

f) other extra charges

For the past claims experience it must be borne in mind that each statistic contains chance fluctuations which depend on the size of the portfolio and the distribution in the different risk classes. The size of these fluctuations is outlined in a table based on mathematical principles [2]. The insurance companies are compelled to use the figures of the compound statistic when the credibility of their own statistics is not sufficiently reliable. An exception from this rule is possible only on the basis of well-founded reasons.

\section{I2. EFFECTS ON THE MARKET}

Today it would be premature to express an opinion about the effects of the cancellation of price-fixing agreements but no serious disturbances have been reported so far. A certain displacement in the portfolios can, however, be observed. This trend should continue because premium rates are different and policyholders will soon become aware of this feature. 
Under pressure of free competition the fairness of the tariff should improve and this trend should continue after the complete liberalisation of the motor insurance market.

\section{LIST OF REFERENCES}

[I] Bormann/Cuntz/Völker: Die Neuordnung der deutschen Kraftfahrtversicherung, Verlag Kommentator, Frankfurt I961.

[2] Bormann/Cuntz/Völker: Die Neuordnung der deutschen Kraftfahrtversicherung, Ergänzungsband, Verlag Kommentator, Frankfurt 1962.

[3] BRUgGeR, W.: Allgemeine Bedingungen für die Kraftverkehrsversicherung, Erläuterungen zu den Änderungen, Versicherungsrecht Nr. I/1962.

[4] Das Marktproblem in der deutschen Kraftverkehrsversicherung, Herausgeber W. Gerlach, Verlag Duncker und Humblot, Berlin I958.

[5] Merring, J.: Die Versicherung von Kraftfahrschäden in der Bundesrepublik Deutschland, Transactions of the XVIth International Congress of Actuaries, Brüssel ro6o.

[6] Menring, J.: Strukturprobleme der Kraftfahrt-Haftpflichtversicherung, Blätter der Deutschen Gesellschaft für Versicherungsmathematik, I960, Band V, Heft I.

[7] Mehring, J.: Die Schadenstruktur in der Kraftfahrt-Haftpflichtversicherung von Personenwagen, Blätter der Deutschen Gesellschaft für Versicherungsmathematik, 1962, Band VI, Heft I. 